\title{
The Removal Effect of Pollutants and Components in Extracellular Polymeric Substances from Aerobic Granular Sludge in Simultaneous Removal of Organic Matter and Ammonia Nitrogen
}

\author{
Y. Ren, ${ }^{\mathrm{a},{ }^{*}}$ Y. Liu, ${ }^{\mathrm{b}}$ G. Hao, ${ }^{\mathrm{b}}$ Y. Wen, ${ }^{\mathrm{b}}$ Z. Chen, ${ }^{\mathrm{b}}$ and L. Yan ${ }^{\mathrm{b}, *}$ \\ aSchool of Municipal and Environmental Engineering, \\ Harbin Institute of Technology, Harbin 150090, PR China \\ bSchool of Resource and Environment, Northeast Agricultural University, \\ Harbin 150030, PR China
}

doi: 10.15255/CABEQ.2014.2137

Original scientific paper Received: October 21, 2014 Accepted: December 6, 2015

\begin{abstract}
This work studied the removal effect of pollutants and the components in extracellular polymeric substances (EPS) extracts obtained from aerobic granular sludge (AGS) with high concentration of ammonia nitrogen and analyzed EPS using Fourier-transformed IR (FTIR) spectrometer. The AGS demonstrated perfect performance in simultaneous removal of organic matter and ammonia nitrogen, and the removal rates were both maintained above $90 \%$, the stable nitrite accumulation was achieved as well. The main particle size was more than $1.4 \mathrm{~mm}$ and the higher electrical conductivity was caused by the existences of organic and mineral fractions in EPS. $\mathrm{Ca}, \mathrm{K}, \mathrm{Fe}, \mathrm{Mg}, \mathrm{Zn}$, and $\mathrm{Cu}$ were the main mineral elements contained in EPS extracts. Mineral fractions of EPS improve the stabilization of the AGS.
\end{abstract}

Key words:

extracellular polymeric substances, aerobic granular sludge, ammonia nitrogen, mineral fraction, organic fraction

\section{Introduction}

Biological processes, such as activated sludge and granular sludge are widely used to remove organic pollutants as well as inorganic pollutants, such as metallic elements ${ }^{1-3}$, which are known to be potentially toxic, and impact the performance of biological waste treatment processes ${ }^{4}$. Granular sludge is a dense aggregate of microorganisms, minerals, and microbial produced compounds such as extracellular polymeric substances (EPS) ${ }^{5,6}$.

Compared to traditional activated sludge technology, AGS as a new type of microbe auto-immobilization technology, has many advantages, such as compact structure, fast settling velocity, higher sludge concentration, and ability to withstand high organic loading ${ }^{7,8}$. Many researches mainly try to study the operating conditions ${ }^{9}$, microbiological properties $^{10,11}$, physicochemical characteristics ${ }^{12,13}$, and extracellular polymeric substances of granular sludge ${ }^{14,15}$. The AGS technology is used for treating all kinds of wastewater, including organic matter, nitrogen, phosphorus, and toxic substances ${ }^{16-19}$.

EPS is a complex high-molecular-weight mixture of polymers in AGS. The EPS is a network bacteria embedded ${ }^{20}$, has a significant effect on the

"Corresponding author: Tel.: +86 451 86283697; fax: +86 45155191170

E-mail address: renyuanhit@163.com, yan1198@163.com. physicochemical properties of AGS, including structure, surface charge, flocculation, settling properties, and adsorption ability; plays a crucial role in biological wastewater treatment ${ }^{21-23}$. It not only results from active bacterial secretion, but also from cell lysis and effluent molecules ${ }^{24}$. EPS is considered as an organic product with mineral cations bound. Guibaud et al. ${ }^{25}$ have showed that some mineral particles, such as manganese oxides and iron oxy-hydroxides in the EPS extract can improve the ability of the EPS binding lead or cadmium cations. However, the mineral fraction of the EPS extracts, which is too often neglected in EPS studies, can affect the physicochemical properties of EPS ${ }^{26}$.

The aim of this study is to investigate the removal effect of pollutants and the components, including the organic and mineral fractions, and especially to evaluate the mineral fraction in EPS to improve the stabilization of the AGS.

\section{Methods}

\section{Experimental sludge and wastewater}

The experimental sludge used was the aerobic granular sludge with simultaneous removal of organic matter and ammonia nitrogen taken in a steady lab run for more than one year ${ }^{27}$. A synthetic 
wastewater was used. Glucose and sodium acetate were used as carbon sources, and ammonium chloride was the nitrogen source. Details of the synthetic wastewater composition are given in Table 1 . $0.6 \mathrm{~mL} \mathrm{~L}^{-1}$ trace element was added to the wastewater above to supply the necessary elements for microbial growth ${ }^{27}$.

Table 1 -Components of the synthetic wastewater

\begin{tabular}{l|cc|c}
\hline Components & $\begin{array}{c}\text { Concentration } \\
\left(\mathrm{mg} \mathrm{L}^{-1}\right)\end{array}$ & Components & $\begin{array}{c}\text { Concentration } \\
\left(\mathrm{mg} \mathrm{L}^{-1}, \text { except } \mathrm{pH}\right)\end{array}$ \\
\hline $\mathrm{COD}$ & $100-350$ & $\mathrm{pH}$ & $7.5-8.0$ \\
$\mathrm{NH}_{4}^{+}-\mathrm{N}$ & $80-120$ & $\mathrm{CaCl}_{2}$ & 34 \\
$\mathrm{PO}_{4}^{3-}-\mathrm{P}$ & $5-10$ & $\mathrm{MgSO}_{4} \cdot 7 \mathrm{H}_{2} \mathrm{O}$ & 21 \\
\hline
\end{tabular}

\section{Reactor description}

Plexiglas column SBR reactor was used as experimental set-up. The height of the reactor was $60 \mathrm{~cm}$, with inner diameter of $10 \mathrm{~cm}$, and effective volume of $4.2 \mathrm{~L}$. The volumetric exchange ratio of liquid was $50 \%$. The aeration system comprised an air compressor and a microporous aerator (sintering sand core) on the bottom. The aeration quantity was controlled by gas flowmeter. A programmable time controller was used to regulate the air compressor to realize the intermittent operation. The reactor was operated for 4 cycles every day. The cycles were distributed as follows: 10 minutes of feeding, 330 minutes of aeration, 5 minutes of settling, and 15 minutes of effluent withdrawal. Control parameters: the operating temperature was room temperature $\left(20^{\circ} \mathrm{C}\right)$, dissolved oxygen (DO) was controlled between 6.0 and $8.0 \mathrm{mg} \mathrm{L}^{-1}$. The sludge concentration was $4500 \mathrm{mg} \mathrm{L}^{-1}$. The $\mathrm{pH}$ in reactor was controlled by adding 1:14 $\mathrm{H}_{2} \mathrm{SO}_{4}$ and $0.03 \mathrm{~mol} \mathrm{~L}^{-1}$ $\mathrm{NaHCO}_{3}$.

\section{Determination of physicochemical properties}

The analyses of COD, $\mathrm{NH}_{4}^{+}-\mathrm{N}, \mathrm{NO}_{2}^{-}-\mathrm{N}, \mathrm{NO}_{3}^{-}-\mathrm{N}$ and mixed liquid suspended solids (MLSS) were performed according to the respective standard method $^{28}$. UV absorbance was measured with a UV-1800 spectrophotometer (Shimadzu Co., Tokyo, Japan). The $\mathrm{pH}$ values were measured by a $\mathrm{pH}$ meter (pHS-3C, Shanghai Weiye Co., Ltd., China). DO concentration was determined by a DO meter (FG4-FK, Mettler Toledo Co., Ltd, Switzerland). The particle sizes were measured using an image analysis system (Image-pro Express 5.1, Media Cybernetics). The redox potential and the electrical conductivity were determined by $\mathrm{pHS}-3 \mathrm{C}$ precision pH meter (saturated calomel electrode, SCE; platinum electrode) and conductivity meter, respectively.

\section{EPS extraction method}

No standard extraction method has been developed for EPS. Chemical extraction protocols have also shown to contaminate the EPS extracts by impurities or carrying over of the extractant itself ${ }^{26}$. According to some studies, the molecular movement is enhanced, which accelerates the EPS dissolution $^{29}$, so heating is the most effective method for EPS extraction due to its minimal cell lysis and more EPS extracted ${ }^{30,31}$. In a typical procedure: $100 \mathrm{~mL}$ of sample was centrifuged (4000 rpm, 5 minutes), and the supernatant was discarded, and then diluted with deionized water to its original volume. The diluted sample was heated $\left(80{ }^{\circ} \mathrm{C}, 10\right.$ minutes $)$, centrifuged $(8000 \times \mathrm{g}, 20$ minutes $)$, and then filtered through $0.22 \mu \mathrm{m}$ cellulose membrane filters. The obtained EPS extracts were stored at $-20{ }^{\circ} \mathrm{C}$ for further analysis.

\section{Analysis of EPS}

\section{Analysis of organic matter}

Protein measurement was performed using a modified Lowry method ${ }^{32}$. Bovine Serum Albumin (BSA) was used as standard. Polysaccharide concentration was determined using the Anthrone method $^{33}$. Glucose was used as standard. Each measurement was undertaken on duplicate samples.

\section{Analysis of mineral fractions}

The mineral fractions in EPS were determined according to literature ${ }^{26}$. The details are as followed: A total of $3 \mathrm{~mL}$ of EPS were digested through the addition of $2 \mathrm{~mL}$ of hydrogen peroxide for 24 hours. Then, $3 \mathrm{~mL}$ of nitric acid and $1 \mathrm{~mL}$ of perchloric acid were added to the solution. Digestion was again performed after another 24 hours. After the second digestion, the samples were diluted with ultrapure water to $50 \mathrm{~mL}$ and then filtered through $0.22 \mu \mathrm{m}$ cellulose nitrate membrane filters. Inductively coupled plasma optical emission spectrometry (ICP-OES, Perkin Elmer Optima 8300, America) determined the contents of mineral fractions.

\section{Fourier-transformed IR (FTIR) spectroscopy}

The FT-IR spectra of the EPS samples were recorded using an FTIR spectrometer (Avatar 370, Thermo Nicolet, America). The freeze-dried EPS samples were initially mixed with $\mathrm{KBr}(1 \mathrm{mg}$ of EPS per $100 \mathrm{mg}$ of $\mathrm{KBr}$ ). The $\mathrm{KBr}$ pellets were heated until dried, and the dried samples were kept under vacuum in desiccators prior to use. The blank was corrected using a clean $\mathrm{KBr}$ pellet. The spectra were obtained with a resolution of $4 \mathrm{~cm}^{-1}$ and a scan range of 400-4000 $\mathrm{cm}^{-1}$. 


\section{Results and discussion}

\section{Particle size distribution characteristics of granules}

Fig. 1 is particle size distribution of granules in stable operation reactor. It was observed that the main particle size of the AGS was more than 1,400 $\mu \mathrm{m}$, of which the masses of particle sizes that were less than $500 \mu \mathrm{m}, 500-830 \mu \mathrm{m}, 830-1,000 \mu \mathrm{m}$, $1000-1400 \mu \mathrm{m}$, more than $1400 \mu \mathrm{m}$ accounted for $15.73 \%, 3.32 \%, 0.49 \%, 19.86 \%, 60.60 \%$, respectively, of the total mass of AGS. The mature granular sludge was tawny, its outline was spheroidic or round, its boundary was clear (Fig. 2a). There are many cocci and a small number of bacillus distributing on the surface of granular sludge (Fig. 2b). The mature granular sludge having bigger particles, and dense structure has an excellent settling property $^{34}$. Compared with traditional sludge (particles of traditional activated sludge are smaller than 150 $\mu \mathrm{m}$, loose sludge flocs, settling rate no more than $10 \mathrm{~m} \mathrm{~h}^{-1}$ ), the average settling rate of the mature granular is $3.30 \mathrm{~cm} \mathrm{~s}^{-1}$. The particle size of the granules was influenced by many factors, such as the $\mathrm{COD} / \mathrm{N}$, short operating time (60 days) and the configuration of reactors ${ }^{10}$. COD/N ratio plays a significant role in nitrifying sludge granulation. To some extent, there was a trend towards larger average granule diameter under higher $\mathrm{COD} / \mathrm{N}$ ratio and load ${ }^{35}$. In contrast, Tsuneda et al. ${ }^{36}$ obtained smaller granule diameter of granular sludge which took longer because the influent did not contain organic substrate, whereas Gao et al. ${ }^{37}$ also obtained a smaller granule diameter because of lower substrate load. Moreover, granule diameter of granular sludge was related to the operating time and configuration of reactors, granule diameter of granular sludge increased with the extension of operating time generally $^{38}$. However, the effect of reactor configuration

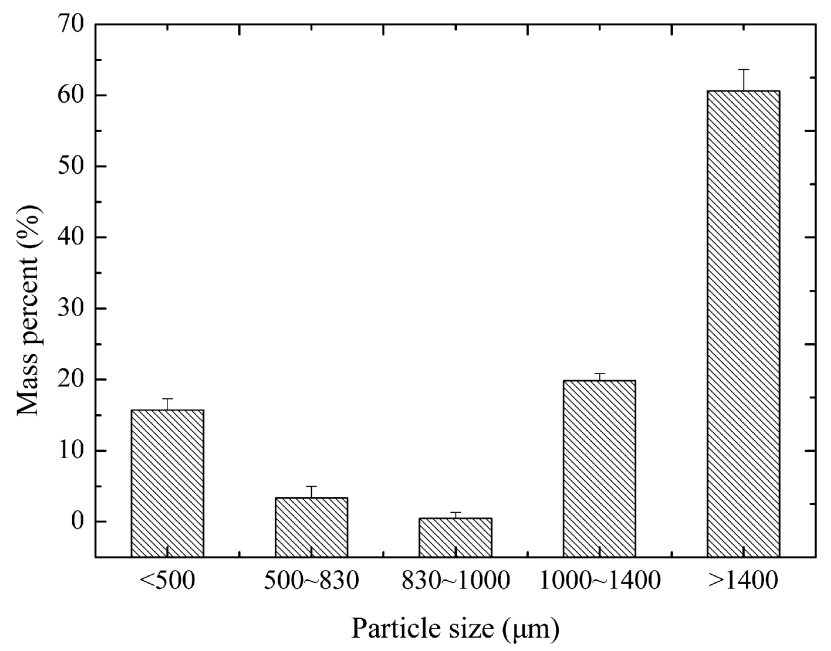

Fig. 1 - Particle size distribution of granules

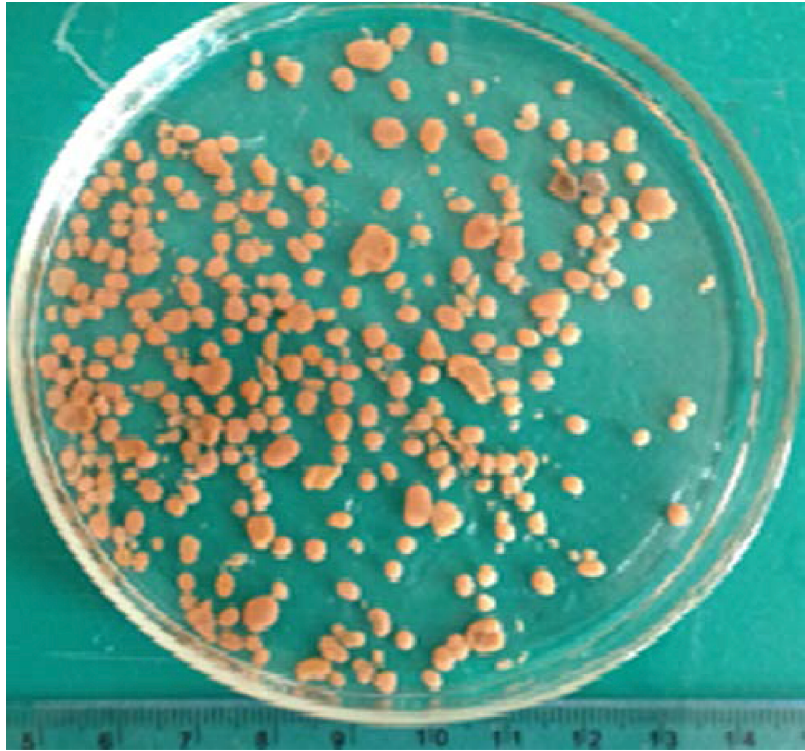

a

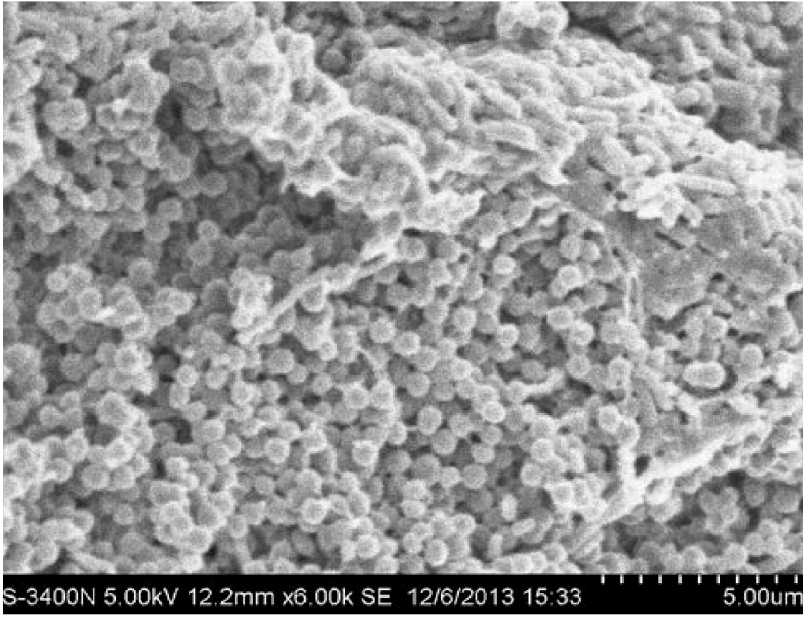

$\mathrm{b}$

Fig. 2 - Shape (a) and SEM observation (b) of AGS

on granule diameter of granular sludge is more complicated, which needs further research ${ }^{10}$.

\section{Removal ratio of AGS on pollutants}

Removal ratio of $A G S$ on $\mathrm{NH}_{4}^{+}-\mathrm{N}$

Influent and effluent $\mathrm{NH}_{4}^{+}-\mathrm{N}$ concentrations and $\mathrm{NH}_{4}^{+}-\mathrm{N}$ removal efficiency of AGS is shown in Fig. 3. The effluent $\mathrm{NH}_{4}^{+}-\mathrm{N}$ concentrations were stable between 0.08 and $8.78 \mathrm{mg} \mathrm{L}^{-1}$ at a volumetric exchange ratio of $50 \%$. From days 19 to 63 , the $\mathrm{NH}_{4}^{+}-\mathrm{N}$ removal efficiencies improved between 92.33 and $99.92 \%$. The $\mathrm{NH}_{4}^{+}-\mathrm{N}$ removal capacity indicated a good enrichment of nitrifiers, which could have resulted in the formation of AGS. According to the literature, which have well demonstrated good performance in nitrogen removal due to the composition of granular microbial communi- 


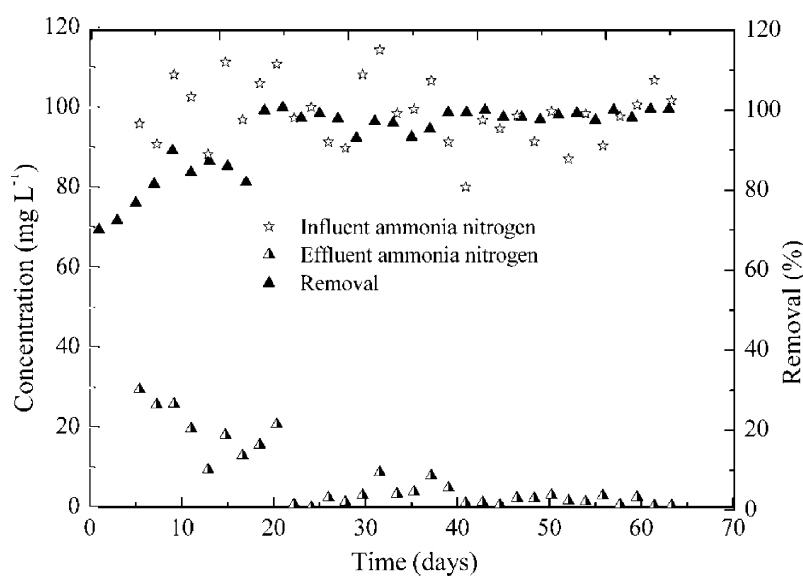

Fig. 3 - Influent and effluent $\mathrm{NH}_{4}^{+}-\mathrm{N}$ concentrations and $\mathrm{NH}_{4}^{+}-\mathrm{N}$ removal efficiency of $\mathrm{AGS}$

ties, including heterotrophic, aerobic bacteria grown on the outside, ammonium-oxidizing bacteria in the middle, and facultative and anaerobic bacteria in the core of the granules ${ }^{39,40}$. Wei et al. ${ }^{41}$ reported that the average $\mathrm{NH}_{4}^{+}-\mathrm{N}$ removal efficiency kept at $96 \%$ for a long time in the aerobic granule-based bioreactor. The $\mathrm{NH}_{4}^{+}-\mathrm{N}$ removal efficiency was $99 \%$ running $8 \mathrm{~h}$ with the use of granular sludge investigated by Cydzik-Kwiatkowska et al. ${ }^{42}$ However, from days 1 to 17 in the experiment, the $\mathrm{NH}_{4}^{+}-\mathrm{N}$ removal efficiencies were only between 69.30 and $89.22 \%$, the average removal efficiency was $92.66 \%$. Compared to the literature, lower removal efficiency resulted from the small specific area of particles due to their larger sizes in this experiment, $\mathrm{NH}_{4}^{+}-\mathrm{N}$ incompletely exposed to the aerobic bacteria grown outside. Otherwise, because of the dense structure of the granules and the sticky EPS accumulated on the surface of bacterial cells for adhesion during the granulation process, $\mathrm{NH}_{4}{ }^{+} \mathrm{N}$ cannot be oxidized by the ammonium-oxidizing bacteria in the middle.

\section{Removal ratio of AGS on COD}

Fig. 4 shows the influent and effluent COD concentrations and COD removal efficiency of AGS. Unstable behavior of practical wastewater with a wide fluctuation of influent organics was observed. From days 1 to 35, the influent COD concentrations increased from 106.35 to $303.14 \mathrm{mg} \mathrm{L}^{-1}$. From days 23 to 49 , the effluent COD concentrations decreased stepwise from 91.71 to $1.31 \mathrm{mg} \mathrm{L}^{-1}$. Afterwards, the effluent COD concentrations were between 2.93 and $28.85 \mathrm{mg} \mathrm{L}^{-1}$. From days 31 to 63 , the removal efficiency of COD was between 80.59 and $99.37 \%$. The average removal efficiency was $90.22 \%$. The result of this study indicated good performance in organics removal in accordance with those performed in other researches. $\mathrm{Ni}$ et al. ${ }^{43}$ reported that the average COD removal effi-

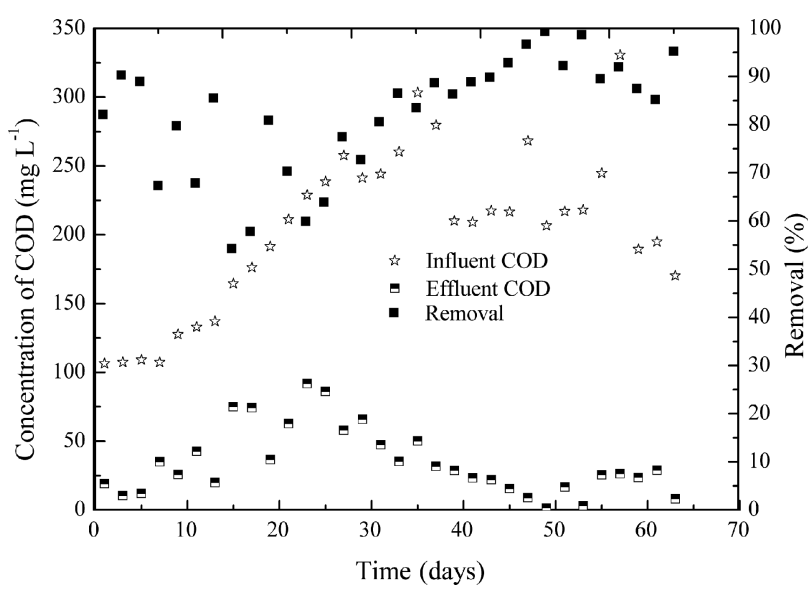

Fig. 4 - Influent and effluent COD concentrations and COD removal efficiency of $A G S$

ciency of aerobic granulation kept at $90 \%$ for a long time in the bioprocess. The organics removal efficiency of AGS cultivated by Schwarzenbeck et $a l .{ }^{44}$ reached $90 \%$ after complete granulation. The researches above have well documented the perfect removal efficiency of AGS on organics in the treatment of various organic wastewater.

\section{Effluent nitrite and nitrate of AGS}

As shown in Fig. 5, the effluent concentration of nitrite nitrogen was between 12.52 and $57.59 \mathrm{mg} \mathrm{L}^{-1}$, and nitrate nitrogen concentration maintained below $8.56 \mathrm{mg} \mathrm{L}^{-1}$. Nitrite accumulation rates $\left(\mathrm{NO}_{2}-\mathrm{N} / \mathrm{NO}_{\mathrm{x}}-\mathrm{N}\right)$ were between 78.81 and $96.83 \%$ in the effluent, so that partial nitrification occurred in the reactor. Nitrite bacteria could be confirmed as the dominant nitrifying bacteria in the system. Controlling the DO concentration, temperature, SRT, $\mathrm{pH}$, free ammonia (FA), and free nitrous acid (FNA) in the reactor could achieve nitrite accumulation. In this experiment, DO controlled between 6.0 and $8.0 \mathrm{mg} \mathrm{L}^{-1}$, the inflow concentration of nitrite nitrogen controlled

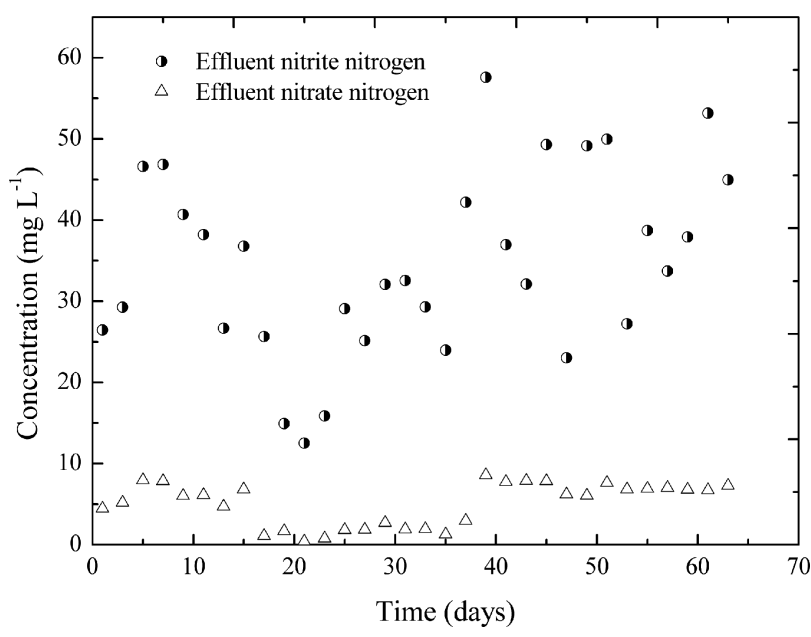

Fig. 5 - Effluent $\mathrm{NO}_{2}^{-}-\mathrm{N}$ and $\mathrm{NO}_{3}^{-}-\mathrm{N}$ concentrations of $\mathrm{AGS}$ 
below $4 \mathrm{mg} \mathrm{L}^{-1}$, at room temperature $\left(25^{\circ} \mathrm{C}\right)$, and SRT controlled at $15 \mathrm{~d}$, were adverse to nitrite accumulation. Therefore, according to analysis, high $\mathrm{pH}$ (between 7.5 and 8.0) and the FA concentration (1.20-1.71 $\left.\mathrm{mg} \mathrm{L}^{-1}\right)$ might be the main reasons for nitrite accumulation. This result was in accordance with the literature ${ }^{45-47}$. Besides, delamination of AGS might also be a reason for the nitrite accumulation. Shi et al. ${ }^{39}$ reported that the amount of nitrosation bacteria was more than that of nitrifying bacteria in AGS, and most of the nitrosation bacteria that adhered to the surface of granules could obtain sufficient DO to oxidate ammonia nitrogen to nitrite nitrogen. While nitrifying bacteria had distributed in the inner portion of the granules lacking in DO, the oxidizing ability was inhibited. This corresponded to the experimental results.

\section{Analysis of EPS}

The organic fraction and physicochemical properties of EPS

The organic fraction and physicochemical properties of EPS are summarized in Table 2. The results show that the electrical conductivity was $2.25 \cdot 10^{2} \mu \mathrm{m} \mathrm{cm}^{-1}$, and redox potential was $367.2 \mathrm{mV}$. Recently, a few studies on the electrical conductivity of EPS have been performed, whose theory and the influence factors need to be further studied.

Table 2 - Organic fraction and physicochemical properties of EPS

\begin{tabular}{l|c|lc}
\hline \multicolumn{1}{c|}{ Indexes } & Results & \multicolumn{1}{c}{ Indexes } & Results \\
\hline $\begin{array}{l}\text { Electrical } \\
\text { conductivity }\end{array}$ & $2.25 \cdot 10^{2} \mu \mathrm{m} \mathrm{cm}^{-1}$ & Protein & $38.36 \mathrm{mg} \mathrm{g}^{-1}$ \\
$\begin{array}{l}\text { Redox } \\
\text { potential }\end{array}$ & $367.2 \mathrm{mV}$ & Polysaccharide & $18.67 \mathrm{mg} \mathrm{g}^{-1}$ \\
& $\begin{array}{l}\text { Protein/ } \\
\text { polysaccharide }\end{array}$ & 2.05 \\
\hline
\end{tabular}

The organic fraction of EPS is mainly composed of protein and polysaccharide. The results show that each gram of MLSS, the contents of polysaccharide and protein in the EPS extracted by the heating method were 18.67 and $38.36 \mathrm{mg}$, respectively, and the ratio of protein/polysaccharide 2.05 . The data for protein and polysaccharide contents obtained for EPS are in accordance with the concentrations observed by Sheng et al. ${ }^{48}$ Moreover, the large yields of both are due to the fact that, during the extraction procedure by heating, the proteins and polysaccharides could have hydrolysed ${ }^{49}$, and the bound EPS, strongly attached to activated sludge, was allowed to be extracted, since both kinds of EPS exist in the sludge in this extraction procedure. In addition, the result of the ratio of protein/polysaccharide is in accordance with the one reported by Liu and Fang ${ }^{50}$, and confirms that the EPS extracted in this study were not contaminated by intracellular materials from bacteria of AGS. These authors have shown that the ratio of protein/ polysaccharide from activated sludge varies from 0.5 to 21.2. When the ratio is high, the EPS are predominantly composed of protein, thus the protein originated mainly from cell lysis or exocellular enzymes.

\section{Mineral fractions}

Fig. 6 shows the chemical composition of the mineral fractions in the EPS. Many different inorganic cations were present in EPS samples. Phosphorus was the main mineral compound (data not presented), whereas $\mathrm{Ca}, \mathrm{K}, \mathrm{Fe}, \mathrm{Mg}, \mathrm{Zn}$ and $\mathrm{Cu}$ were the main metallic elements. The presence of $\mathrm{Ca}$ and $\mathrm{Fe}$ confirms their role in the maintenance of the granular structure, and they are necessary for the granulation of sludge, and integrated in the granule in important quantities ${ }^{51}$. $\mathrm{Ca}$ and $\mathrm{Fe}$ act as the bridging ions ${ }^{52}$, therefore, the binding of divalent cations with EPS stabilizes the structure of the EPS matrix. Moreover, in the EPS, the ionic nature of cell surfaces and the molecules allows interactions with cations, $\mathrm{Zn}$ and $\mathrm{Cu}$ should be preferentially present inside the bacterial cell due to their biological activity. Due to the presence of various types of binding sites for cations in the organic compounds of the EPS $^{24,26}$, a part of the multivalent inorganic cations, such as $\mathrm{Ca}^{2+}, \mathrm{Mg}^{2+}$, and $\mathrm{Fe}^{2+}$, measured in the EPS extracts, are very likely bound to the organic molecules in the EPS in order to provide structural stability in $\mathrm{AGS}^{53,54}$. Mn and $\mathrm{Ni}$ are the trace elements in the EPS, the contents are 0.008 and $0.017 \mathrm{mg} \mathrm{L}^{-1}$ respectively.

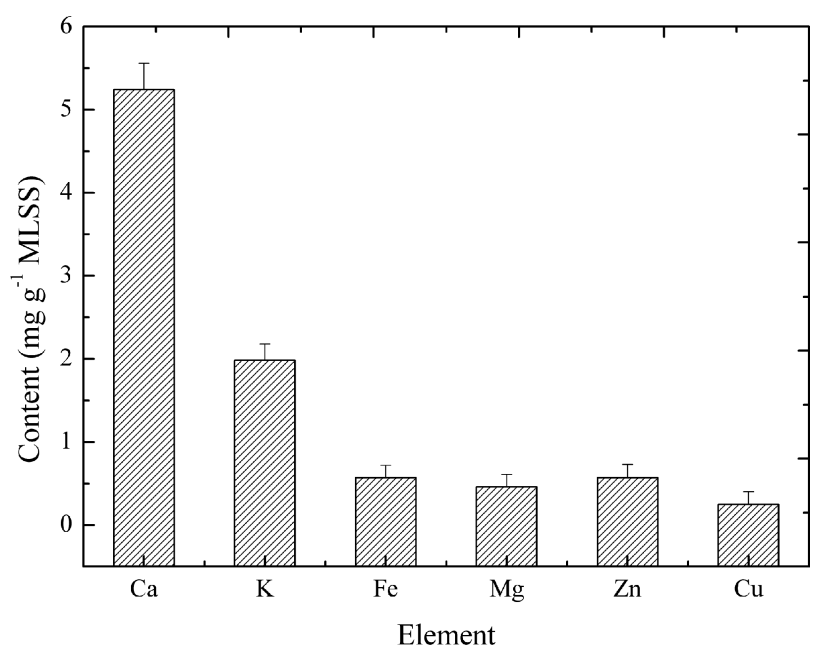

Fig. 6 - Main elements content of the mineral fractions in the EPS ( $m g g^{-1}$, MLSS) 
IR spectra examples of EPS extracted from AGS are represented. The IR spectra show the contribution, as well as the superposition of absorption bands from organic and inorganic compounds, except for absorption bands below $1000 \mathrm{~cm}^{-1}$ which may be essentially attributed to inorganic compounds ${ }^{55}$, such as phosphate or sulfur functional groups. Several intense characteristic bands can be attributed to protein and polysaccharide functional groups. Carboxylic groups, under acid or basic salt form, are responsible for some less intense bands. The stretching vibration of $\mathrm{OH}$ can be observed ${ }^{55}$ at $3392.19 \mathrm{~cm}^{-1}$ as well as $1654.49 \mathrm{~cm}^{-1}$, and a weak symmetric stretching vibration band of $\mathrm{CH}_{2}$ at $2927.57 \mathrm{~cm}^{-1}$ and $1454.26 \mathrm{~cm}^{-1}$. The stretching vibration of C-N observed at $1544.15 \mathrm{~cm}^{-1}$ of proteins. The bands at $1400.51 \mathrm{~cm}^{-1}$ and $1245.86 \mathrm{~cm}^{-1}$ may respectively be assigned to the $\mathrm{C}=\mathrm{O}$ in the carboxylates and carboxylic acids. The absorption peak observed at $1083.46 \mathrm{~cm}^{-1}$ in the range from $1000 \mathrm{~cm}^{-1}$ to $1200 \mathrm{~cm}^{-1}$ is known to be typical of all sugar derivatives ${ }^{56}$. The different functional groups observed in the EPS samples agree with Comte et $a l .{ }^{57}$. Divalent cations are able to link to the phosphate and carboxyl groups. Therefore, FTIR was used to study the functional groups of microbial aggregates and their associated EPS.

\section{Conclusion}

The removal ratio of $\mathrm{COD}$ and $\mathrm{NH}_{4}^{+}-\mathrm{N}$ were analyzed. The AGS demonstrated good performance in simultaneous organic carbon and nitrogen remov$\mathrm{al}$, and the removal rates were 90.22 and $92.66 \%$. The particle size above $0.5 \mathrm{~mm}$ was $84.27 \%$, and the main particle size above $1.4 \mathrm{~mm}$ was $60.60 \%$. The electrical conductivity of EPS was $2.25 \cdot 10^{2}$ $\mu \mathrm{m} \mathrm{cm}{ }^{-1}$, and the mineral fractions of the EPS extract were determined to exist. $\mathrm{Ca}, \mathrm{K}, \mathrm{Fe}, \mathrm{Mg}, \mathrm{Zn}$, and $\mathrm{Cu}$ were the main mineral elements found in EPS extracts, $\mathrm{Mn}$ and Ni were the trace elements in EPS extracts. In this study, the organic and mineral fractions in EPS were studied; however, the relationship between them is unclear. Meanwhile, in the forming process of granular sludge, the function of EPS need further research.

\section{ACKNOWLEDGMENTS}

This work was supported by Young academic backbone support project of Heilongjiang Province (NO. 1254G010), Academic backbone support project of Northeast Agricultural University (15XG07), The National Key Technology $R \& D$ Program (2013BAD21B01).

\section{References}

1. Kavitha, S., Adish Kumar, S., Kaliappan, S., Adish Kumar, S., Ick Tae Yeom, Rajesh Banu, J., Accelerating the sludge disintegration potential of a novel bacterial strain Planococcus jake 01 by $\mathrm{CaCl}_{2}$ induced deflocculation, Bioresour. Technol. 175 (2014) 396. doi: http://dx.doi.org/10.1016/j.biortech.2014.10.122

2. Kavitha, S., Adish Kumar, S., Kaliappan, S., Ick Tae Yeom, Rajesh Banu, Improving the amenability of municipal waste activated sludge for biological pretreatment by phase-separated sludge disintegration method, Bioresour. Technol. 169 (2014) 700 doi: http://dx.doi.org/10.1016/j.biortech.2014.07.065

3. Wei, D., Li, M., Wang, X., Han, F., Li, L., Guo, J., Ai, L., Fang, L., Liu, L., Du, B., Wei, Q., Extracellular polymeric substances for Zn (II) binding during its sorption process onto aerobic granular sludge, J. Hazard. Mater. 301 (2016) 407.

doi: http://dx.doi.org/10.1016/j.jhazmat.2015.09.018

4. Zhang, Z., Deng, R., Cheng, Y., Zhou, Y., Zhang, X., Wang, $H$., Jin, R., Buayi, X., Behavior and fate of copper ions in an anammox granular sludge reactor and strategies for remediation, J. Hazard. Mater. 300 (2015) 838. doi: http://dx.doi.org/10.1016/j.jhazmat.2015.08.024

5. $L i, A$., $L i, X$., Yu, H., Aerobic sludge granulation facilitated by activated carbon for partial nitrification treatment of ammonia-rich wastewater, Chem. Eng. J. 218 (2013) 253. doi: http://dx.doi.org/10.1016/j.cej.2012.12.044

6. Liu, Y., Tay, J. H., State of the art of biogranulation technology for wastewater treatment, Biotechnol. Adv. 22 (2004) 533.

doi: http://dx.doi.org/10.1016/j.biotechadv.2004.05.001

7. Thanh, B. X., Visvanathan, C., Aim, R. B., Characterization of aerobic granular sludge at various organic loading rates, Process Biochem. 44 (2009) 242. doi: http://dx.doi.org/10.1016/j.procbio.2008.10.018

8. Gao, D., Yuan, X., Liang, H., Reactivation performance of aerobic granules under different storage strategies, Water Res. 46 (2012) 3315. doi: http://dx.doi.org/10.1016/j.watres.2012.03.045

9. Lochmatter, S. Holliger, C., Optimization of operation conditions for the startup of aerobic granular sludge reactors biologically removing carbon, nitrogen, and phosphorous, Water Res. 59 (2014) 58. doi: http://dx.doi.org/10.1016/j.watres.2014.04.011

10. Liang, Y. H., Li, D., Zeng, H. P., Zhang, C. D., Zhang, Z., Rapid start-up and microbial characteristics of partial nitrification granular sludge treating domestic sewage at room temperature, Bioresour. Technol. 196 (2015) 741. doi: http://dx.doi.org/10.1016/j.biortech.2015.08.003

11. Lv, Y., Wan, C., Liu, X., Zhang, Y., Lee, D. J., Tay, J. H., Drying and re-cultivation of aerobic granules, Bioresour. Technol. 129 (2013) 700. doi: http://dx.doi.org/10.1016/j.biortech.2012.12.178

12. Liu, Y., Yang, S., Qin, L., Tay, J. H., A thermodynamic interpretation of cell hydrophobicity in aerobic granulation, Appl. Microbiol. Biotechnol. 64 (2004) 410. doi: http://dx.doi.org/10.1007/s00253-003-1462-9

13. Liu, Y., Yang, S., Tay, J. H., Liu, Q., Qin, L., Li, Y., Cell hydrophobicity is a triggering force of biogranulation, Enzyme Microb. Technol. 34 (2004) 371. doi: http://dx.doi.org/10.1016/j.enzmictec.2003.12.009

14. Mahendran, B., Jared Fein, Steven N. Liss, The effects of extracellular polymeric substances on the formation and stability of biogranules, Water Res. 82 (2015) 104. 
15. Wang, R., Peng. Y., Cheng, Z., Ren, N., Understanding the role of extracellular polymeric substances in an enhanced biological phosphorus removal granular sludge system, Bioresour. Technol. 169 (2014) 307. doi: http://dx.doi.org/10.1016/j.biortech.2014.06.040

16. Basheer, F., Farooqi, I. H., Biodegradation of p-cresol by aerobic granules in sequencing batch reactor, J. Environ. Sci. 24 (2012) 2012 doi: http://dx.doi.org/10.1016/S1001-0742(11)60988-1

17. Zhou, X., Chen, C., Wang, A., Liu, L., Ho, K. L., Ren, N., Lee, $D$. J., Rapid acclimation of methanogenic granular sludge into denitrifying sulfide removal granules, Bioresour. Technol. 102 (2011) 5244. doi: http://dx.doi.org/10.1016/j.biortech.2011.01.049

18. Zhang, Y., Tay, J. H., Alternated phenol and trichloroethylene biodegradation in an aerobic granular sludge reactor, Biochem. Eng. J. 106 (2016) 1. doi: http://dx.doi.org/10.1016/j.bej.2015.10.026

19. Othman, I., Aznah, A. N. Z., Rosman, U. N. H., Harum, H. N. D., Chelliapan, $S$. S. D., Livestock wastewater treatment using aerobic granular sludge, Bioresour. Technol. 133 (2013) 630 doi: http://dx.doi.org/10.1016/j.biortech.2013.01.149

20. Liu, H., Fang, H. P., Extraction of extracellular polymeric substances (EPS) of sludges, J. Biotechnol. 95 (2002) 249.

doi: http://dx.doi.org/10.1016/S0168-1656(02)00025-1

21. Sheng, G., $Y u, H$., Li, $X$., Extracellular polymeric substances (EPS) of microbial aggregates in biological wastewater treatment systems: A review, Biotechnol. Adv. 28 (2010) 882 .

doi: http://dx.doi.org/10.1016/j.biotechadv.2010.08.001

22. Caudan, C., Filali, A., Spérandio, M., Girbal-neuhauserr, $E$., Multiple EPS interactions involved in the cohesion and structure of aerobic granules, Chemosphere. 117 (2014) 262.

doi: http://dx.doi.org/10.1016/j.chemosphere.2014.07.020

23. Zhu, L., Lv, M., Dai, $X$., Yu, Y., Qi, H., Xu, X., Multiple EPS interactions involved in the cohesion and structure of aerobic granules, Bioresour. Technol. 107 (2012) 46 doi: http://dx.doi.org/10.1016/j.biortech.2011.12.008

24. Neu, J., Wingender, T. R., Flemming, H. C., Microbial Extracellular Polymeric Substances, Characterization, Structure and Function. Berlin, Springer, (1999).

25. Guibaud van Hullebusch, G., Bordas, E., F., Joussein, Abzac P d', E., Joussein, Sorption of Cd (II) and Pb (II) by exopolymeric substances (EPS) extracted from activated sludges and pure bacterial strains, modeling of the metal/ ligand ratio effect and role of the mineral fraction, Bioresour. Technol. 100 (2009) 2959

26. Pd'Abzac, Bordas, F., Joussein, E., Eric van, H., Piet, N. L. $L$., Gilles, $G$., Characterization of the mineral fraction associated to extracellular polymeric substances (EPS) in anaerobic granular sludges, Environ. Sci. Technol. 44 (2010) 412.

doi: http://dx.doi.org/10.1021/es901912g

27. Yan, L., Liu, Y., Ren, Y., Ying, Z., Analysis of the characteristics of short-cut nitrifying granular sludge and pollutant removal processes in a sequencing batch reactor, Bioprocess Biosyst. Eng. 37 (2014) 125. doi: http://dx.doi.org/10.1007/s00449-013-1006-3

28. APHA. Standard Methods for the Examination of Water and Wastewater. 20th ed.: American Public Health Association/ American Water Works Association/Water Environment Federation, Washington D.C. USA, 1998.
29. $\mathrm{Li}$, $X$., Yang, S., Influence of loosely bound extracellular polymeric substances (EPS) on the flocculation, sedimentation and dewaterability of activated sludge, Water Res. 41 (2007) 1022 doi: http://dx.doi.org/10.1016/j.watres.2006.06.037

30. Brown, M. J., Lester, J. N., Comparison of bacterial extracellular polymer extraction methods, Appl. Environ. Microbiol. 40 (1980) 179.

31. Bura Cheung, R. M., Liao, B., Finlayson, J., Droppo, I. G., Leppard, $G$., Composition of extracellular polymeric substances in the activated sludge floc matrix, Water Sci. Technol. 37 (1998) 325.

32. Lowry, O. H., Rosebrough, N. J., Farr, A. L., Randall, R. $G$., Protein measurement with the Folin phenol reagent, J. Biol. Chem. 193 (1951) 265.

33. Gaudy, A. F., Colorimetric determination of protein and carbohydrate, Ind. Water Wastes. 7 (1962) 17.

34. Campos, J. L. S, Garrido-Fernández, J. M., Méndez, R., Lema, J. M., Nitrification at high ammonia loading rates in an activated sludge unit, Bioresour. Technol. 68 (1999) 141. doi: http://dx.doi.org/10.1016/S0960-8524(98)00141-2

35. $\mathrm{Li}, \mathrm{A}$., Yang, S., $\mathrm{Li}, \mathrm{X}$., Gu, J., Microbial population dynamics during aerobic sludge granulation at different organic loading rates, Water Res. 42 (2008) 3552. doi: http://dx.doi.org/10.1016/j.watres.2008.05.005

36. Tsuneda, S., Nagano, T., Hoshino, T., Eijri, Y., Noda, N., Hirata, A., Characterization of nitrifying granules produced in an aerobic upflow fluidized bed reactor, Water Res. 37 (2003) 4965. doi: http://dx.doi.org/10.1016/j.watres.2003.08.017

37. Gao, J., Guo, J., Influence of SBR drainage height and diameter ratio on aerobic sludge granulation, China Environ. Sci. 28 (2008) 512.

38. Shi, $X$., Yu, H., Sun, Y., Huang, $X$., Characteristics of aerobic granules rich in autotrophic ammonium-oxidizing bacteria in a sequencing batch reactor, Chem. Eng. J. 147 (2009) 102. doi: http://dx.doi.org/10.1016/j.cej.2008.06.037

39. Figueroa, M., Mosquera-Corral, A., Campos, J. L., Men$d a z, K$., Treatment of saline wastewater in SBR aerobic granular reactors, Water Sci. Technol. 58 (2008) 479. doi: http://dx.doi.org/10.2166/wst.2008.406

40. Ni, B., Yu H., Mathematical modeling of aerobic granular sludge: A review, Biotechnol. Adv. 28 (2010) 895 doi: http://dx.doi.org/10.1016/j.biotechadv.2010.08.004

41. Wei, D., Wei, S., Zhang, Y., Qiao, Z., Yao, Z., Zhao, W., Zhao, J., Chen, G., Wei, Q., Aerobic granulation and nitrogen removal with the effluent of internal circulation reactor in start-up of a pilot-scale sequencing batch reactor, Bioprocess Biosyst. Eng. 35 (2012) 1489. doi: http://dx.doi.org/10.1007/s00449-012-0738-9

42. Cydzik-Kwiatkowska, A., Zielińska, M. K., Bernat, Wojnowska-Baryła, I., Wojnowska-Baryla, I., Truchan, T., Treatment of high-ammonium anaerobic digester supernatant by aerobic granular sludge and ultrafiltration processes, Chemosphere 90 (2013) 2208. doi: http://dx.doi.org/10.1016/j.chemosphere.2012.09.072

43. Ni, B., Xie, W., Yu, H., Wang, Y., Wang, G., Dai, X., Granulation of activated sludge in a pilot-scale sequencing batch reactor for the treatment of low-strength municipal wastewater, Water Res. 43 (2009) 751. doi: http://dx.doi.org/10.1016/j.watres.2008.11.009

44. Schwarzenbeck, N., Borges, J. M., Wilderer, P. A., Treatment of dairy effluents in an aerobic granular sludge sequencing batch reactor, Appl. Microbiol. Biotechnol. 66 (2005) 711 . doi: http://dx.doi.org/10.1007/s00253-004-1748-6 
45. Wan, C., Sun, S., Lee, D. J., Liu, X., Wang, L., Yang, X., $P a n, X$., The effect of $\mathrm{pH}$ on partial nitrification-denitrification rate of high ammonia-containing wastewater, Bioresour. Technol. 142 (2013) 517.

doi: http://dx.doi.org/10.1016/j.biortech.2013.04.120

46. Tokutomi, T., Operation of a nitrite-type airlift reactor at low DO concentration, Water Sci. Technol. 49 (2004) 81 .

47. Zhang, B., Chen, Z., Qiu, Z., Jin, M., Chen, Z., Lin, J., Wang, $X$., Wang, J., Dynamic and distribution of ammonia-oxidizing bacteria communities during sludge granulation in an anaerobic-aerobic sequencing batch reactor, Water Res. 45 (2011) 6207.

doi: http://dx.doi.org/10.1016/j.watres.2011.09.026

48. Sheng, G., $Y u, H$., $Y u, Z$., Extraction of extracellular polymeric substances from the photosynthetic bacterium Rhodopseudomonas acidophila, Appl. Microbiol. Biotechnol. 67 (2005) 125

doi: http://dx.doi.org/10.1007/s00253-004-1704-5

49. Karapanagiotis, Rudd, N. K., Sterritt, T. R. M., Lester, J. N., Extraction and characterisation of extracellular polymers in digested sewage sludge, J. Chem. Technol. Biotechnol. 44 (1989) 107.

doi: http://dx.doi.org/10.1002/jctb.280440203

50. Liu, Y., Fang, H. H. P., Influences of Extracellular Polymeric Substances (EPS) on Flocculation, Settling, and Dewatering of Activated Sludge. Environ. Sci. Technol. 33 (2003) 237.

doi: http://dx.doi.org/10.1080/10643380390814479
51. Vlyssides, Barampouti, A., Mai, E. M. S., Influence of ferrous iron on the granularity of a UASB reactor, Chem. Eng. J. 146 (2009) 49. doi: http://dx.doi.org/10.1016/j.cej.2008.05.011

52. Li, H., Wen, Y., Cao, A., Huang, J., Zhou, Q., Samasundaran, $P$., The influence of additives $\left(\mathrm{Ca}^{2+}, \mathrm{Al}^{3+}\right.$, and $\left.\mathrm{Fe}^{3+}\right)$ on the interaction energy and loosely bound extracellular polymeric substances (EPS) of activated sludge and their flocculation mechanisms, Bioresour. Technol. 114 (2012)188. doi: http://dx.doi.org/10.1016/j.biortech.2012.03.043

53. Keiding, K., Nielsen, P. H., Desorption of organic macromolecules from activated sludge: Effect of ionic composition, Water Res. 31 (1997) 1665. doi: http://dx.doi.org/10.1016/S0043-1354(97)00011-0

54. Liu, L., Gao, D., Zhang, M., Fu, Y., Comparison of $\mathrm{Ca}^{2+}$ and $\mathrm{Mg}^{2+}$ enhancing aerobic granulation in SBR, J. Hazard. Mater. 181 (2010) 382. doi: http://dx.doi.org/10.1016/j.jhazmat.2010.05.021

55. Hui, F., Labbé, J. P., Lédion, J., Analysis of mineral fraction of biofilms by infrared absorption spectrometry, Tech. Sci. Methods. 5 (2008) 21.

56. Badireddy, A. R., Chellam, S., Gassman, P. L., Engelhard, H. M., Lea, A. S., Rosso, K. M., Role of extracellular polymeric substances in bioflocculation of activated sludge microorganisms under glucose-controlled conditions, Water Res. 44 (2010) 4505. doi: http://dx.doi.org/10.1016/j.watres.2010.06.024

57. Zhang, J., Liu, W., Sun, W., Xu, N., Ni, J., Study on Adsorption Behavior of $\mathrm{Pb}^{2+}$ and $\mathrm{Cd}^{2+}$ by Extracellular Polymeric Substances, J. Beijing. Univ. TCM. 49 (2013) 514. 